\title{
Mortality of the defoliator Euselasia eucerus (Lepidoptera: Riodinidae) by biotic factors in an Eucalyptus urophylla plantation in Minas Gerais State, Brazil
}

\author{
JOSÉ C. ZANUNCIO ${ }^{1}$, JORGE B. TORRES ${ }^{2}$, CAMILLA A.Z. SEDIYAMA ${ }^{3}$, FABRICIO F. PEREIRA ${ }^{1}$, \\ PATRIK L. PASTORI ${ }^{3}$, EDUARDO D. WERMELINGER ${ }^{4}$ and FRANCISCO S. RAMALHO ${ }^{5}$ \\ ${ }^{1}$ Departamento de Biologia Animal, Universidade Federal de Viçosa \\ Av. P.H. Rolfs s/n, Centro, 36571-000 Viçosa, MG, Brasil \\ ${ }^{2}$ Departamento de Agronomia e Fitossanidade, Universidade Federal Rural de Pernambuco \\ Av. Dom Manoel de Medeiros s/n, Dois Irmãos, 52171-900 Recife, PE, Brasil \\ ${ }^{3}$ Departamento de Fitotecnia, Universidade Federal de Viçosa \\ Av. P.H. Rolfs s/n, Centro, 36571-000 Viçosa, MG, Brasil \\ ${ }^{4}$ Departamento de Ciências Biológicas, Escola Nacional de Saúde Pública, Fundação Oswaldo Cruz \\ Rua Leopoldo Bulhões, 1.480, Manguinhos, 21040-360 Rio de Janeiro, RJ, Brasil \\ ${ }^{5}$ Embrapa Algodão/Unidade de Controle Biológico, Rua Oswaldo Cruz, 1.143 \\ Centenário, 58107-720 Campina Grande, PB, Brasil \\ Manuscript received on May 12, 2008; accepted for publication on August 25, 2008; \\ presented by ALEXANDER W.A. KELLNER
}

\begin{abstract}
Euselasia eucerus (Hewitson, 1872) (Lepidoptera: Riodinidae) is a Brazilian native species commonly found in Eucalyptus plantations. Biotic mortality factors of this defoliator were studied in a Eucalyptus urophylla plantation in Minas Gerais State, Brazil aiming to identify natural enemies and their impact on this insect. Euselasia eucerus had biotic mortality factors during all development stages. The most important were Trichogramma maxacalii Voegelé and Pointel, 1980 (Hymenoptera: Trichogrammatidae) during egg stage (48.9\%), a tachinid fly (Diptera: Tachinidae) during larval stages (10\%) and Itoplectis sp. (Hymenoptera: Ichneumonidae) during pupal stage (52.2\%). The parasitism rate was higher in the basal part of the plant canopy (37.8\%).
\end{abstract}

Key words: Eulophidae, fungus, Ichneumonidae, Pentatomidae, Scelionidade, Trichogramma.

\section{INTRODUCTION}

Lepidoptera pests can cause significant damage to eucalyptus plantations in Brazil (Zanuncio et al. 1993, 1998, 2001, Bernardino et al. 2007). Euselasia eucerus (Hewitson, 1872) (Lepidoptera: Riodinidae), also reported as Euselasia apisaon (Dalman, 1823) (Zanuncio et al. 1990, Murta et el. 2008), is a Brazilian native insect and its caterpillars are commonly found in Eucalyptus spp. plantations in São Paulo, Rio Grande do Sul, Santa Catarina and Minas Gerais States, Brazil in

Correspondence to: José Cola Zanuncio

E-mail: zanuncio@ufv.br outbreaks conditions (Zanuncio et al. 1994). The entire developmental cycle of E. eucerus takes place on Eucalyptus trees, this insect lays its egg clusters on their leaves and its caterpillars are gregarious and pupate on leaves of Eucalyptus spp. (Zanuncio et al. 1990). Euselasia eucerus eggs are parasitized by Trichogramma maxacalii Voegelé and Pointel, 1980, Trichogramma demoraesi Nagaraja, 1983 and Trichogramma acacioi Brun, Moraes and Soares, 1984 (Hymenoptera: Trichogrammatidae); its caterpillars and its pupae are predated by Podisus nigrispinus (Dallas, 1851), Brontocoris tabidus (Signoret, 1852), Supputius cincticeps (Stål, 1860) 
and Alcaeorrhynchus grandis (Dallas, 1851) (Heteroptera: Pentatomidae) and its pupa are parasitized by the fungus Paecilomyces fumosoroseus (Wize) (Brun et al. 1983, Oliveira et al. 2000, Murta et al. 2008). However, pupal parasitism of E. eucerus and the impact of other biological factors (Zanuncio et al. 1998a, b) on mortality of this pest have not been studied.

The importance of each natural enemy species on the biological control of insect pests can be estimated by evaluating their attack rate (Zanuncio et al. 1998a, b, Landis et al. 2000, Kean et al. 2003, Thies et al. 2003, Soares et al. 2007). However, sampling after parasitoid releases to determine the percentage of individuals attacked may not be adequate to estimate parasitism rate (van Driesche et al. 1991, Pastori et al. 2007). Problems occur when parasitism relationships such as stage or susceptible instars, and size or habitat are not known or when mortality factors including predation and parasitoid emergence occur in a different stage from that attacked (Pratissoli et al. 2003). Another problem can occur when host mortality during handling time by natural enemies and losses by migration are not considered. Therefore, samples taken at different stages of the pest in its habitat can show the frequency, the diversity and the potential impact of each factor on pest population, which is frequently limited by parasitoids and predators (Hawkins 1988, Kruess and Tschantke 1994, Michaud 2004).

The objective of this work was to identify parasitoids and predators and to quantify their impact on different stages of the defoliator E. eucerus in a plantation of E. urophylla in the Municipality of Caeté, Minas Gerais State, Brazil.

\section{MATERIALS AND METHODS}

This work was carried out in a two- to three-year-old (ca. $5.0 \mathrm{~m}$ height) E. urophylla plantation in the Municipality of Caeté, Minas Gerais State, Brazil (19 $52^{\prime} 48^{\prime \prime} \mathrm{S}$ $43^{\circ} 40^{\prime} 12^{\prime \prime} \mathrm{W}$ ). The impact of biotic factors (natural enemies) on mortality of eggs, caterpillars and pupae of $E$. eucerus was evaluated in a second- to third-generation outbreak of this pest. The first sampling (September 1997) collected individuals of E. eucerus at all development stages, from leaves and branches of the basal part of nine Eucalyptus plants from each three plots with a total of 27 plants. All material collected was brought to the laboratory where it was reared to the end of each stage in order to identify mortality causes per stage of $E$. eucerus.

A second sampling was made in the same area and plots in January 1998. Plant levels of Eucalyptus trees were divided into upper, middle and lower thirds to study the distribution of eggs, caterpillars and pupae mortality factors of E. eucerus as function of plant height. One branch per plant ( \pm 100 leaves) containing different developmental stages of E. eucerus was collected in each of these parts. The samples were collected from nine plants and from three plots at the same place where the first sampling was performed.

The egg clusters of E. eucerus were individualized in glass tubes closed with plastic film Magipack ${ }^{\mathrm{TM}}$, until eclosion of caterpillars or egg parasitoids. Pupae of E. eucerus were isolated in $9.0 \times 1.2 \mathrm{~cm}$ Petri dishes until emergence of adults of E. eucerus or parasitoids. Finally, caterpillars of this pest were counted and maintained in groups, in nylon mesh cages with branches of E. urophylla until its pupation or death. Pupae were then maintained in similar conditions until emergence of $E$. eucerus or parasitoids.

The relationship between egg parasitism and size of egg clusters of E. eucerus was analyzed by simple linear regression and that of oviposition of this pest and parasitism rate as a function of Eucalyptus plant height was studied by analysis of variance and the test of Tukey.

Egg parasitoids were sent to Dr. Roberto A. Zucchi from the University of São Paulo, São Paulo State, Brazil, and hymenopteran pupae parasitoids were separated into morphospecies and sent to Dra. Angélica M. Penteado-Dias from the Federal University of São Carlos, São Carlos, São Paulo State, Brazil, for identification.

\section{RESULTS}

In the first sampling, 10,046 eggs of E. eucerus were collected with an average of $54.6 \pm 20.2$ eggs per egg cluster (mean $\pm \mathrm{SD}$ ). A total of 4,778 eggs (52.1\%) did not yield caterpillars; $91.4 \%$ of them were parasitized by T. maxacalii and $8.6 \%$ did not show embryonic development. Egg parasitism was positively correlated with 


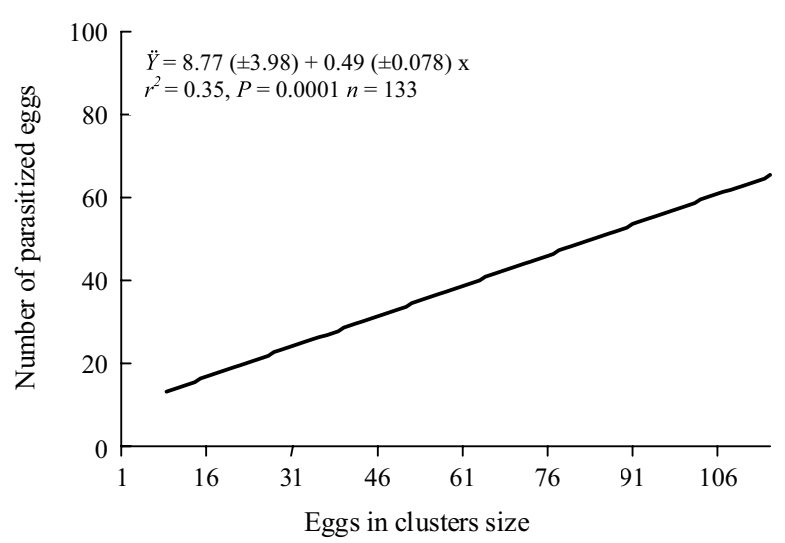

Fig. 1 - Effect of egg cluster size of Euselasia eucerus (Lepidoptera: Riodinidae) on natural parasitism by Trichogramma maxacalii collected in the Municipality of Caeté, Minas Gerais State, Brazil.

the size of egg clusters $\left(\mathrm{y}=8.77+0.49 \mathrm{x}, \mathrm{r}^{2}=0.35\right.$, $\mathrm{F}=67.6, \mathrm{P}<0.001, \mathrm{n}=133$ ) (Fig. 1).

Mortality of E. eucerus caterpillars by biotic factors may be from either predation by Pentatomidae or from larval/pupal parasitism by Tachinidae flies. Tachinid parasitoids were responsible for 7.5 and $2.1 \%$ mortality of caterpillars and pupae of this pest, respectively (Table I), and no parasitoids were observed emerging from caterpillars. The number of caterpillars killed by pentatomid predators was not quantified since the sampling was carried out in a fixed time and the total population of E. eucerus caterpillars was not estimated. Moreover, prey carcasses or fragments are difficult to distinguish in the field. Therefore, all such observed data arise from five males, four females and one fifth instar nymph of B. tabidus. One male and two females of $S$. cincticeps were also found preying caterpillars of E. eucerus. Six eggs clusters of B. tabidus (237 eggs) were found and $34.4 \%$ of which yielded nymphs and $60.0 \%$ were parasitized by Trissolcus brochymenae (Ashmead, 1881) (Hymenoptera: Scelionidae).

Of 105 E. eucerus pupae collected, 52.5\% were parasitized by Itoplectis sp. (Hymenoptera: Ichneumonidae), $2.5 \%$ by Galeopsomyia sp. (Hymenoptera: Eulophidae) and $10.0 \%$ by a fungus, respectively. Besides this, $7.5 \%$ of pupae of this insect were unviable due to unknown factors.

The number of eggs per egg cluster of E. eucerus was similar in the three levels of the Eucalyptus trees,
$54.2 \pm 23.1,49.8 \pm 20.6$ and $47.4 \pm 21.3$ in the basal, middle and apical levels of the plants, respectively. The parasitism by $T$. maxacalii on 27,40 and 47 egg clusters showed higher values, $37.8 \pm 26.1 \%$ in the apical third and $29.9 \pm 39.8 \%$ in the medium third than the $18.3 \pm$ $34.5 \%$ in the lower third of Eucalyptus trees.

Mortality due to parasitism of E. eucerus pupae by Itoplectis sp. was greater than any other factor, with 47.7, 61.7 and $29.3 \%$ in the basal, middle and apical levels of the plants, respectively. Ranking of pupae mortality factors was an unknown factor, a fungus species, and parasitism by Aprostocetus sp. (Hymenoptera: Eulophidae), a tachinid fly and a Quadrastichus sp. (Hymenoptera: Eulophidae) (Table I). The parasitoid Galeopsomyia sp. (Hymenoptera: Eulophidae) was not found during the second sampling.

\section{DISCUSSION}

The high parasitism rate of E. eucerus eggs by $T$. maxacalli indicates that the oviposition behavior (laying its eggs in clusters) of this pest favors the impact of this parasitoid which can parasitize most eggs of a cluster as happened in this study and with high impact on populations of this herbivore (Murta et al. 2008). This is similar to that observed for Trichogramma species (Hymenoptera: Trichogrammatidae) on eggs of Choristoneura fumiferana (Clemens, 1865) (Lepidoptera: Tortricidae) and Diaphania nitidalis (Stoll, 1781) (Lepidoptera: Pyralidae) as the most important and the key mortality factor of these pests, possible due to the fact that this species lay its eggs in clusters (Quayle et al. 2003). On the other hand the Trichogramma species did not represent an important mortality factor of Tortrix viridana (Linnaeus, 1758) (Lepidoptera: Tortricidae) which lay eggs isolated and dispersed ( Du Merle 1983) and Traumatocampa ispartaensis (Do Ganlar and Avci 2001) (Lepidoptera: Notodontidae) duet to a protection by a cement like substance (Avci 2003).

Although predation rates by pentatomid predators did not allow a good evaluation of their efficiency, their importance in this ecosystem is suggested by:

1) the number of B. tabidus pairs mating or preying on caterpillars of E. eucerus in Eucalyptus plants and in the understory vegetation and; 


\section{TABLE I}

Percentage mortality of caterpillars and pupae by different factors and adult emergence of Euselasia eucerus (Lepidoptera: Riodinidae) collected in an Eucalyptus urophylla plantation in the Municipality of Caeté, Minas Gerais State, Brazil.

\begin{tabular}{l|c|c|c|c}
\hline \multirow{2}{*}{ Factors } & \multirow{2}{*}{ Sampling size } & \multicolumn{3}{c}{ Part of tree canopy } \\
\cline { 3 - 5 } & & Lower & Middle & Upper \\
\hline Egg parasitism & 5635 eggs & & & \\
\hline Trichogramma maxacalii & & 37.8 & 29.9 & 18.3 \\
\hline Non eclosion of caterpillars & & 19.4 & 1.1 & 2.4 \\
\hline Caterpillar/pupae parasitism by & 483 caterpillars & & & \\
\hline Tachinidae flies & & 7.5 & 2.1 & 0.0 \\
\hline Pupae parasitism by & 105 pupae & & & \\
\hline Itoplectis sp. & & 47.7 & 61.7 & 29.3 \\
\hline Aprostocetus sp. & & 10.1 & 4.3 & 0.0 \\
\hline Quadrastichus sp. & & 2.0 & 0.0 & 0.0 \\
\hline Unknown factors & & 20.1 & 21.3 & 15.9 \\
\hline Fungus & & 10.5 & 6.4 & 0.0 \\
\hline Emergence of adults & & 2.5 & 4.3 & 51.0 \\
\hline
\end{tabular}

2) the finding of six egg clusters of this predator, being $60.6 \%$ of them parasitized by $T$. brochymenae.

The high population level of this parasitoid suggests that $B$. tabidus had been present in the area for several generations because egg clusters of $P$. nigrispinus showed a parasitism rate of $27.5 \%$ by Telenomus podisi Ashmead, 1893 (Hymenoptera: Scelionidae) and T. brochymenae in areas with previous releases of this pentatomid. Comparatively, areas with limited releases of this predator only during the sampling period and areas without release showed parasitism rates of 8.8 and 2.4\% (Torres et al. 1996/1997, Zanuncio et al. 2000).

The Hymenoptera parasitoids Itoplectis sp. and Galeopsomyia sp. were not previously recorded in pupae of E. eucerus or in any other Eucalyptus defoliator caterpillar species in Brazil (Brun et al. 1983) but species of this group have been collected in the others eucalypt species (Zanuncio et al. 2008, Pereira et al. 2008 a, b). Tachinidae adults emerging during the pupal stage of $E$. eucerus accounted for $10.0 \%$ of pupa mortality of this pest. Trichogramma soaresi (Nagaraja, 1983), T. acacioi and T. maxacalii (Hymenoptera: Trichogrammatidae) are known as egg parasitoids of Euselasia species. Trichogramma maxacalii has previously been found parasitizing eggs of Euselasia euploea eucerus (Hewitson,
1872), Euselasia hygenius occulta Stichel, 1919 and E. eucerus (Lepidoptera: Riodinidae) (Oliveira et al. 2000).

Pupal parasitism by a fungus of the genus Paecilomyces and by a tachinid fly also occurred. The factors that determine the diversity and the impact of parasitoids on 285 moth species in the United Kingdom showed that the number of studies conducted on the host species, the host habitat and the host plant architecture were correlated. Among eight variables, habitat and plant architecture presented higher correlation with the impact of the parasitoids. This author also pointed out that the number of generations per year of a Lepidoptera pest showed positive correlation with parasitoid diversity. He also discusses 74 cases of biological control by parasitism of Hymenoptera and Diptera species with values above $40 \%$. Although parasitism rate around $90 \%$ was not enough to control pests in many cases, this was mainly due to the non-synchronization of the parasitoid with its host. For this reason, successful control of these moths was achieved only in restricted areas (Hawkins 1988). This shows that pest management strategies to increase natural mortality of insect pests should include conservation or augmentative impact of natural enemies (Bragança et al. 1998a, b, Jahnke et al. 2006).

Euselasia eucerus suffers considerable mortality during all development stages in Eucalyptus plantation 
in Brazil including egg mortality by $T$. maxacalii and pupae mortality by Itoplectis sp. The role of predatory Pentatomidae as control agents against caterpillars of E. eucerus has high potential against defoliator pests in eucalyptus plantations in Brazil but needs to be studied further (Zanuncio et al. 1994).

Biotic mortality factors of E. eucerus were found during all developmental stages of this pest in an E. urophylla plantation in the Municipality of Caeté, Minas Gerais State, Brazil. Most important ones were T. maxacalii, tachinid flies and Itoplectis sp. during egg, larvae, and pupae stages of this pest, respectively.

\section{ACKNOWLEDGMENTS}

To Dra. Angélica M. Penteado-Dias, Federal University of São Carlos and to Dr. Roberto A. Zucchi of ESALQ/USP, São Paulo State, Brazil, for the identification of egg and pupae parasitoids, respectively. To Dr. Patrick De Clercq, University of Gent, Belgium, for reviewing the manuscript. To Coordenação de Aperfeiçoamento de Pessoal de Nível Superior (CAPES), Conselho Nacional de Desenvolvimento Científico e Tecnológico (CNPq), Fundação de Apoio à Cultura, Ensino, Pesquisa e Extensão (FACEPE) and Fundação de Amparo à Pesquisa do Estado de Minas Gerais (FAPEMIG) for supporting this research.

\section{RESUMO}

Euselasia eucerus (Hewitson, 1872) (Lepidoptera: Riodinidae) é uma espécie brasileira nativa, comumente encontrada em plantios de Eucalyptus. Um estudo da mortalidade por fatores bióticos desse desfolhador foi feito em um plantio de Eucalyptus urophylla no Estado de Minas Gerais, Brasil, com o objetivo de identificar os inimigos naturais e seu impacto sobre esse lepidóptero. Euselasia eucerus possui fatores bióticos de mortalidade durante todas as suas fases de desenvolvimento. Os mais importantes foram Trichogramma maxacalii Voegelé e Pointel, 1980 (Hymenoptera: Trichogrammatidae) durante a fase de ovo (48,9\%), um Diptera: Tachinidae durante a fase de larva (10\%) e Itoplectis sp. (Hymenoptera: Ichneumonidae) durante a fase pupal (52,2\%). A taxa de parasitismo foi mais elevada na parte basal de plantas de eucalipto $(37,8 \%)$.

Palavras-chave: Eulophidae, Fungos, Ichneumonidae, Pentatomidae, Scelionidade, Trichogramma.

\section{REFERENCES}

AVCI M. 2003. Parasitism of egg-batches of the cedar processionary moth Traumatocampa ispartaensis in Turkey. Phytoparasitica 31: 118-123.

BERnARdino AS, ZANuncio TV, ZANuncio JC, Lima ER AND SERRÃo JE. 2007. Note on gynandromorphism in the eucalyptus defoliator Thyrinteina arnobia (Stoll, 1782) (Lepidoptera: Geometridae). An Acad Bras Cienc 79: 235-237.

BRAgAnÇA MAL, Souza O AND ZANUnCIO JC. 1998a. Environmental heterogeneity as a strategy for pest management in Eucalyptus plantations. For Ecol Manage 102: 9-12.

Bragança MAL, Zanuncio JC, Picanço MC AND LARANJEIRO AJ. 1998b. Effects of environmental heterogeneity on Lepidoptera and Hymenoptera populations in Eucalyptus plantations in Brazil. For Ecol Manage 103: 287-292.

Brun GP, Moraes GWG And Soares AL. 1983. Três espécies novas de Trichogrammatidae parasitóides de lepidópteros desfolhadores de mandioca e eucalipto. Pesqui Agropecu Brás 19: 805-810.

Du Merle P. 1983. Les facteurs de mortalité des oeufs de Tortrix viridana L. (Lep., Tortricidae). II. Parasitisme par un Trichogramma (Hym., Trichogrammatidae) et "maladies". Agronomie 3: 359-367.

HAWKINS BA. 1988. Species diversity in the third and fourth trophic levels: Patterns and mechanisms. J Anim Ecol 57: 137-162.

JAHnKe SM, REDAelli LR AND DiefenbaCh LMG. 2006. Parasitismo em Phyllocnistis citrella Stainton (Lepidoptera: Gracillariidae) em pomares de citros em Montenegro, RS. Neotrop Entomol 35: 357-363.

Kean J, Wratten S, Tylianakis J and Barlow N 2003. The population consequences of natural enemy enhancement, and implications for conservation biological control. Ecol Lett 6: 604-612.

Kruess A AND TschantKe T. 1994. Habitat fragmentation, species loss, and biological control. Science 264 $1581-1584$

Landis DA, Wratten ST and Gurr GM. 2000. Habitat management to conserve natural enemies of arthropod pests in agriculture. Annu Rev Entomol 45: 175-201.

MichAUD JP. 2004. Natural mortality of Asian citrus psyllid (Homoptera: Psyllidae) in central Florida. Biol Control 29: $260-269$. 
Murta AF, Ker FTO, Costa DB, Espírito-SAnto MM AND FARIA ML. 2008. Efeitos de remanescentes de Mata Atlântica no controle biológico de Euselasia apisaon (Dahman) (Lepidoptera: Riodinidae) por Trichogramma maxacalii (Voegelé e Pointel) (Hymenoptera: Trichogrammatidae). Neotrop Entomol 37: 229-232.

Oliveira HN, Zanuncio JC, Pratissoli D AND CRUZ I. 2000. Parasitism rate and viability of Trichogramma maxacalii (Hym.: Trichogrammatidae) parasitoid of the Eucalyptus defoliator Euselasia apisaon (Lep.: Riodinidae), on eggs of Anagasta kuehniella (Lep.: Pyralidae). For Ecol Manage 130: 1-6.

PAstori PL, Monteiro LB, Botton M AND Pratissoli D. 2007. Capacidade de parasitismo de Trichogramma pretiosum Riley (Hymenoptera: Trichogrammatidae) em ovos de Bonagota salubricola (Meyrick) (Lepidoptera: Tortricidae) sob diferentes temperaturas. Neotrop Entomol 36: 926-931.

Pereira FF, Zanuncio JC, TAVARes MT, PAstori PL AND JACQUES GC. 2008a. Record of Trichospilus diatraeae (Hymenoptera: Eulophidae) as parasitoid of the eucalypt defoliator Thyrinteina arnobia (Lepidoptera: Geometridae) in Brazil. Phytoparasitica 36: 304-306.

Pereira FF, Zanuncio TV, Zanuncio JC, Pratissoli D AND TAVARES MT. 2008b. Species of Lepidoptera defoliators of eucalypt as new hosts for the polyphagous parasitoid Palmistichus elaeisis (Hymenoptera: Eulophidae). Braz arch biol technol 51: 259-262.

Pratissoli D, Fornazier MJ, Holtz AM, Gonçalves JR, Chioramital AB, ZaGo HB. 2003. Ocorrência de Trichogramma pretiosum em áreas comerciais de tomate, no Espírito Santo, em regiões de diferentes altitudes. Hortic Bras 21: 73-76.

Quayle D, RÉgnière J, CAPpuccino N AND Dupont A. 2003. Forest composition, host-population density, and parasitism of spruce budworm Choristoneura fumiferana eggs by Trichogramma minutum. Entomol Exp Appl 107: 215-227.

SoAres MA, Leite GLD, Zanuncio JC, Rocha SL, DE SA VGM and Serrao JE. 2007. Flight capacity, parasitism and emergence of five Trichogramma (Hymenoptera: Trichogrammatidae) species from forest areas in Brazil. Phytoparasitica 35: 314-318.

Torres JB, Zanuncio JC, Picanço MC ANd Oliveira AC. 1996/1997. Parâmetros poblacionales de tres parasitoides (Hymenoptera: Scelionidae: Encyrtidae) utilizando al depredador Podisus nigrispinus (Heteroptera:
Pentatomidae) como hospedero. Rev Biol Trop 44/45: 233-240.

Thies C, Steffan-Dewenter I And Tscharntke T. 2003. Effects of landscape context on herbivory and parasitism at different spatial scales. Oikos 101: 18-25.

VAN DRIEsche RG, Bellows TS, Elhinton JS, Gould JR AND FERRO DN. 1991. The meaning of percentage parasitism revisited: Solutions to the problem of accurately estimating total losses from parasitism. Environ Entomol 20: 1-7.

Zanuncio JC, GARCia JF, SANTos GP, ZANuncio TV AND NASCIMENTo EC. 1990. Biologia e consumo foliar de lagartas de Euselasia apisaon (Dalman, 1823) (Lepidoptera: Riodinidae) em Eucalyptus spp. Rev Árv 14: 45-54.

Zanuncio JC, Alves JB, Santos GP and Campos WO. 1993. Levantamento e flutuação populacional de lepidópteros associados à eucaliptocultura: VI - Região de Belo Oriente, Minas Gerais. Pesqui Agropecu Bras 28: 1121-1127.

ZANuncio JC, NASCIMENTO EC, GARCIA JF AND ZANUNCIO TV. 1994. Major lepidopterous defoliators of eucalypt, in the Southeast Brazil. For Ecol Manage 65: 53-63.

Zanuncio JC, Mezzomo JA, Guedes RCN and OliVEIRA AC. 1998a. Influence of strips of native vegetation on Lepidoptera associated with Eucalyptus cloeziana in Brazil. For Ecol Manage 108: 85-90.

Zanuncio JC, Oliveira HN, TORRes JB And PratisSOLI D. 2000. Egg parasitoids of Podisus sculptus Distant (Heteroptera: Pentatomidae) in an Eucalyptus plantation in the Brazilian Amazonian Region. Rev Biol Trop 48: 989-992.

ZANuncio JC, Guedes RCN, ZANuncio TV, FABRES AS. 2001. Species richness and abundance of defoliating Lepidoptera associated with Eucalyptus grandis in Brazil and their response to plant age. Austral Ecol 26: 582-589.

Zanuncio JC, Pereira FF, Jacques GC, Tavares MT AND SERRÃo JE. 2008. Tenebrio molitor Linnaeus (Coleoptera: Tenebrionidae), a new alternative host to rear the pupae parasitoid Palmistichus elaeisis Delvare \& LaSalle (Hymenoptera: Eulophidae). The Coleopts Bull 62: 64-66.

Zanuncio TV, Zanuncio JC, Miranda MMM AND Medeiros AGB. 1998b. Effect of plantation age on diversity and population fluctuation of Lepidoptera collected in Eucalyptus plantations in Brazil. For Ecol Manage 108: 91-98. 